\title{
Media Pembelajaran Aktivitas Pengembangan PJOK Untuk Pendidikan Dasar dan Menengah
}

\author{
Made Agus Wijaya ${ }^{a}$, Nyoman Kanca ${ }^{b}$ \\ $a, b$ Prodi PJKR Universitas Pendidikan Ganesha, Bali, Indonesia
}

Corresponding author : wijaya.madeagus@undiksha.ac.id

\begin{tabular}{l}
\hline A R T I C L E I N F O \\
\hline Article history: \\
Received 12 April 2019 \\
Received in revised form 14 \\
April 2019 \\
Accepted 22 April 2019 \\
\hline Keywords: \\
physical education, \\
fitness activities, motion \\
cards \\
\hline
\end{tabular}

\section{Pendahuluan}

Media pembelajaran merupakan bagian penting yang turut menentukan keberhasilan pembelajaran. Guru diarahkan mampu memanfaatkan media pembelajaran yang atraktif dan inovatif sehingga pembelajaran berpusat pada peserta didik untuk mendorong semangat belajar, motivasi, minat, kreativitas, inisiatif, inspirasi, inovasi dan kemandirian dapat terwujud dengan optimal. Pemanfaatan media pembelajaran secara ideal merupakan bagian dari kompetensi pedagogik guru seperti tercantum pada Peraturan Pemerintah Nomor 74 Tahun 2008 tentang Guru.

Pendidikan Jasmani, Olahraga dan Kesehatan (PJOK) sebagai salah satu mata pelajaran yang wajib diberikan pada jenjang pendidikan dasar dan menengah memiliki kedudukan strategis yaitu membentuk karakter peserta didik agar sehat jasmani dan rohani serta menumbuhkan rasa sportifitas (Peraturan Pemerintah RI Nomor 32 Tahun 2013 tentang Standar Nasional Pendidikan). Namun, Kedudukan strategis tersebut belum tercapai secara ideal seperti yang diharapkan.
Hasil survei Tim Pangkalan Data Pendidikan Jasmani dan Olahraga Indonesia (PDPJOI) Asisten Deputi Olahraga Pendidikan Kemenpora RI pada 2.382 satuan pendidikan di 13 kabupaten/ kota menyebutkan bahwa skor rata-rata nasional baru mencapai 520 dari skor maksimal 1.000. Hasil ini menunjukkan bahwa kapasitas satuan pendidikan secara nasional masih berada $52 \%$ dari optimal dilihat dari 3 (tiga) kondisi PJOK yaitu sarana-prasarana, guru, dan kinerja dalam kurun waktu 1 tahun terakhir. Ali Maksum (2011: 1) dengan fokus utama mengungkap kompetensi guru PJOK tingkat SD, SMP, maupun SMA di Jakarta, Surabaya dan Padang menyimpulkan bahwa waktu untuk pengembangan profesionalisme guru relatif masih rendah, yakni $24-42$ menit per hari.

Guru dengan masa kerja rendah cenderung memanfaatkan waktu untuk pemenuhan kebutuhan dasar, sementara itu guru dengan masa kerja lama cenderung memanfaatkan waktu untuk kegiatan yang bersifat produktif. Ditinjau dari derajat kebugaran jasmani peserta didik jua demikian, secara umum derajat kebugaran jasmani peserta didik termasuk pada kategori belum baik. Kebugaran jasmani sebagai salah satu bagian dalam materi ruang lingkup aktifitas 
pengembangan PJOK memberi pengalaman belajar gerak peserta didik antara lain tentang kekuatan otot, daya tahan, kelincahan, kecepatan, power, dan keseimbangan. Agus Amin Sulistiono (2014: 223) dengan subyek penelitian sebanyak 721 peserta didik di Bandung dan Kabupaten Majalengka menemukan, sebanyak 42,27\% peserta didik SD memiliki derajat kebugaran jasmani rendah, peserta didik SMP sebanyak $36,87 \%$, dan sebanyak $46,11 \%$ peserta didik SMA memiliki derajat kebugaran jasmani rendah. Demikinahalnya penelitian Made Budiawan dkk., (2011: 2) yang dilakukan pada SMP di Singaraja, Kabupaten Buleleng-Bali menyimpulkan 91\% peserta didik memiliki tingkat kebugaran jasmani kurang dan kurang sekali.

Paparan mengenai kondisi PJOK mulai dari kebugaran jasmani peserta didik dan masyarakat, sarana-prasarana pembelajaran, guru dan kinerjanya dalam kurun 1 tahun terakhir sampai pada profesionalisme guru di atas memberikan sebuah fakta riil bahwa pembelajaran PJOK membutuhkan perbaikan-perbaikan nyata dalam upaya turut mewujudkan tujuan pendidikan nasional yang gayut dengan kompetensi peserta didik pada abad 21 ini. Salah satu upaya yang dapat ditempuh adalah mewujudkan media pembelajaran PJOK yang memuat karakter positif peserta didik dengan tetap mengutamakan gerak sebagai media mewujudkan tujuan pembelajaran.

Berdasarkan uraian di atas, rumusan permasalahan yang dikemukakan melalui artikel ini adalah: 1) Bagaimanakah tahap pengembangan media pembelajaran berbasis kartu gerak aktifitas pengembangan PJOK untuk pendidikan dasar dan menengah di Kabupaten Buleleng? 2) Bagaimanakah sosok model media pembelajaran berbasis kartu gerak aktifitas pengembangan PJOK untuk pendidikan dasar dan menengah di Kabupaten Buleleng?, serta 3) Bagaimanakah pendapat siswa tentang kartu gerak aktifitas pengembangan PJOK untuk pendidikan dasar dan menengah di Kabupaten Buleleng?

\section{Metode Penelitian}

Penelitian ini merupakan penelitian pengembangan (research and development/ R\&D), dengan mengacu pada desain pengembangan Borg and Gall yang terdiri atas 10 (sepuluh) tahap (Borg, W.R. \& Gall, M.D, 2005). Artikel ini fokus mendeskripsikan tahap ke delapan yaitu uji kelayakan model (operational field testing). Penelitian ini dilaksanakan pada 5 SD, 2 SMP dan 2 SMA/SMK di Kabupaten Buleleng, Bali-Indonesia dengan jumlah peserta didik yang terlibat aktif sebanyak 219 orang. Seluruh siswa yang terlibat dalam penelitian ini telah mendapatkan persetujuan orangtua mengikuti penelitian. Pengumpulan data menggunakan instrumen berupa kuisioner pendapat siswa tentang kartu gerak aktifitas pengembangan. Data dianalisis secara deskriptif kualitatif-kuantitatif.

\section{Hasil}

Guru PJOK di Kabupaten Buleleng saat berdiskusi bersama peneliti mengungkapkan bahwa: 1) guru PJOK di Kabupaten Buleleng umumnya menggunakan media media pembelajaran PJOK berukuran kertas manila yang diletakkan pada tengah-tengah lapangan bermain, 2) mengimplementasikan pembelajaran PJOK melalui model pembelajaran kooperatif, 3 ) belum pernah melihat dan membuat media pembelajaran PJOK berbentuk kartu, dan 4) sangat membutuhkan media pembelajaran PJOK pada materi aktifitas pengembangan. Berdasarkan diskusi untuk analisa kebutuhan tersebut, selanjutnya peneliti mengkaji dan menganalisis materi dan komponen aktifitas pengembangan yang tercantum pada kurikulum di SD, SMP dan SMA/SMK, seperti pada Tabel 01.

\begin{tabular}{lcl}
\hline Jenjang & Kelas & \multicolumn{1}{c}{$\begin{array}{c}\text { Komponen Aktifitas Pengembangan/ } \\
\text { Kebugaran Jasmani }\end{array}$} \\
\hline SD & I -VI & $\begin{array}{l}\text { 1) Kekuatan otot (lengan, bahu, perut, tungkai), } \\
\text { 2) kelentukan, 3) keseimbangan, 4) kordinasi } \\
\text { mata-tangan dan kaki, 5) daya tahan aerobik, 6) } \\
\text { power otot tungkai, 7) kecepatan dan 8) } \\
\text { kelincahan. }\end{array}$ \\
SMP & VII & $\begin{array}{l}\text { 1) Kekuatan, 2) daya ledak/power, 3) } \\
\text { kelenturan, 4) Kelincahan, 5) daya tahan, dan }\end{array}$ \\
SMP & 6) stamina \\
1) Kekuatan, 2) daya tahan, 3) kecepatan, dan \\
4) kelincahan \\
1) Kekuatan, 2) keseimbangan, 3) kelentukan, 4) \\
kelincahan, 5) daya tahan, dan 6) kecepatan
\end{tabular}

Sesuai dengan tabel 01 , terlihat bahwa seluruh komponen kebugaran jasmani telah tercantum pada kurikulum PJOK mulai SD sampai dengan SMA/SMK. Menjadi urgen adalah penyediaan/pemilihan tugas gerak yang disediakan oleh guru PJOK sehingga peserta didik memiliki pengalaman belajar gerak aktifitas pengembangan yang mengesankan dan menyenangkan. Langkah selanjutnya yang ditempuh peneliti adalah merancang draf kartu gerak, melakukan validasi pakar dan praktisi PJOK terhadap draf kartu gerak, melaksanakan revisi sesuai dengan masukan pakar dan praktisi PJOK serta menyelenggarakan ujicoba kelompok besar dan kecil. 
Kartu gerak aktifitas pengembangan merupakan sebuah media pembelajaran yang PJOK yang memuat pilihan tugas gerak pada materi aktifitas pengembangan/ kebugaran jasmani. Kartu gerak ini terdiri atas 2 (dua) sisi yaitu: 1) sisi depan, dan 2) sisi utama. Sisi depan menggambarkan kesenangan terhadap mata pelajaran PJOK/ I $\square$ PJOK (untuk kartu gerak aktifitas pengembangan di SD) dan saranaprasarana serta prosedur melaksanakan tugas gerak (untuk kartu gerak aktifitas pengembangan di SMP dan SMA/SMK). Sedangkan pada sisi utama tercantum: 1) tugas gerak, 2) karakter yang dikonstruksikan/ diinternalisasikan, 3) komponen kebugaran jasmani yang laksanakan, 4) motivasi bergerak untuk siswa SD. Tugas gerak yang disediakan terdiri atas 3 (tiga) tingkat kesulitan yaitu: 1) mudah, dengan warna dasar hijau, 2) sedang, dengan warna dasar kuning, dan 3) sulit, dengan warna dasar merah. Berikut ini pada gambar 01 sampai dengan 03 disajikan sosok kartu gerak seri aktifitas pengembangan untuk SD, SMP dan SMA/SMK.

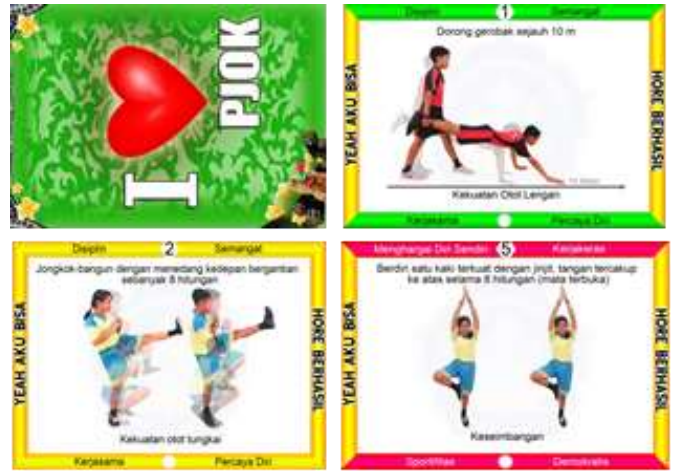

Gambar 01. Kartu Gerak Aktifitas Pengembangan PJOK di SD

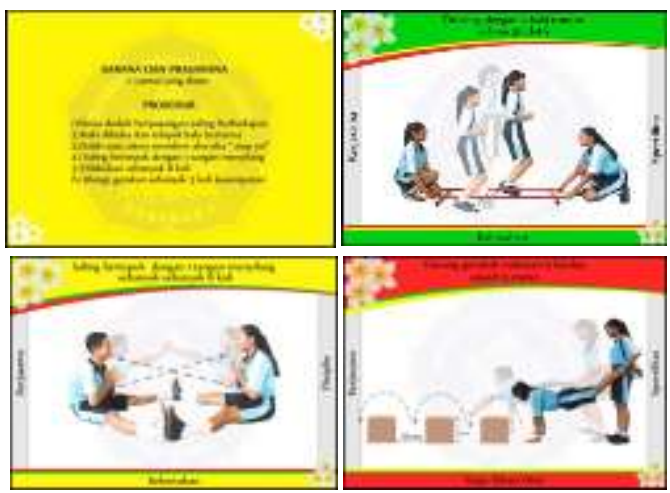

Gambar 02. Kartu Gerak Aktifitas Pengembangan PJOK di SMP

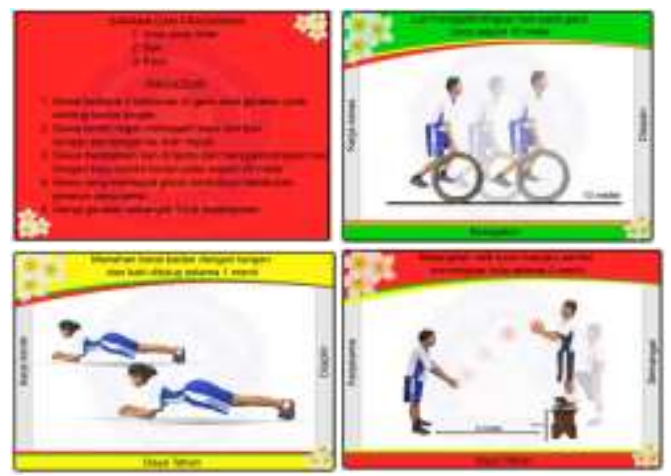

Gambar 03. Kartu Gerak Aktifitas Pengembangan PJOK di SMA/SMK

Peserta didik mulai dari SD, SMP dan SMA/SMK belum pernah memanfaatkan media pembelajaran PJOK dalam bentuk kartu gerak seri aktifitas pengembangan ini. Pada saat ujicoba kelompok kecil, dengan jumlah peserta didik terbatas yaitu 10 - 15 orang peserta didik mengungkapkan setelah mengikuti pembelajaran sebanyak 3 kali pertemuan memberikan pendapatnya seperti pada tabel 02.

Tabel 02.Pendapat Peserta Didik pada Ujicoba Kelompok Kecil Kartu Gerak

\begin{tabular}{clccc}
\hline No & Nama Sekolah & Kelas & $\begin{array}{c}\text { Jumlah } \\
\text { Peserta } \\
\text { didik }\end{array}$ & $\begin{array}{c}\text { Persentase } \\
\text { Peserta didik } \\
\text { Berpendapat } \\
\text { Positif }\end{array}$ \\
\hline 1 & $\begin{array}{l}\text { SD Nomor 1 Bebetin } \\
\text { SD Nomor 2 Bebetin } \\
\text { SMP Negeri 7 }\end{array}$ & V & 14 & $96,20 \%$ \\
3 & $\begin{array}{l}\text { Singaraja } \\
\text { SMP Negeri 5 }\end{array}$ & VII & 14 & $94,50 \%$ \\
4 & $\begin{array}{l}\text { Singaraja } \\
\text { SMK Negeri 1 }\end{array}$ & VIII & 10 & $95,00 \%$ \\
5 & $\begin{array}{l}\text { Sukasada } \\
\text { SMA Negeri 1 }\end{array}$ & X & 10 & $95,85 \%$ \\
6 & Sukasada & XI & 10 & $96,25 \%$ \\
\hline \multicolumn{2}{r}{} & Total & $\mathbf{6 8}$ & $\mathbf{9 5 , 7 6 \%}$ \\
\hline
\end{tabular}
Aktifitas Pengembangan PJOK

Tabel 02 menunjukkan bahwa sebanyak 95,76\% (68 orang peserta didik) memberikan pendapat positif tentang kartu gerak aktivitas pengembangan PJOK ini. Pada awalnya peserta didik merasa canggung melaksanakan pembelajaran aktifitas pengembangan ini, setelah mendapat pendampingan, motivasi dan fasilitasi dari guru PJOK, tugas gerak yang dipilih bersama secara mufakat mulai terstruktur dari tugas gerak mudah - sedang - sulit serta peserta didik merasa senang dan gembira melaksanakan tugas gerak. Pada saat ujicoba kelompok besar yang 
dilaksanakan pada kelas dengan jumlah peserta didik yang sebenarnya berkisar $20-40$ orang peserta didik terlihat hasil seperti tabel 03.

Tabel 03. Pendapat Peserta Didik pada Ujicoba Kelompok Besar Kartu Gerak Aktifitas Pengembangan PJOK

\begin{tabular}{clccc}
\hline No & Nama Sekolah & Kelas & $\begin{array}{c}\text { Jumlah } \\
\text { Peserta } \\
\text { didik }\end{array}$ & $\begin{array}{c}\text { Persentase } \\
\text { Peserta didik } \\
\text { Berpendapat } \\
\text { Positif }\end{array}$ \\
\hline 1 & SD Nomr 1 Menyali & V & 20 & $94,80 \%$ \\
2 & SD Nomr 2 Menyali & V & 21 & $98.60 \%$ \\
3 & SD Nomor 2 Sawan & V & 20 & $94,50 \%$ \\
4 & SMPN 7 Singaraja & VII & 25 & $99,80 \%$ \\
5 & SMPN 5 Singaraja & VIII & 25 & $96,56 \%$ \\
6 & SMAN 1 Sukasada & X & 20 & $99,30 \%$ \\
7 & SMAN 1 Sukasada & XI & 20 & $95,25 \%$ \\
\hline & & Total & $\mathbf{1 5 1}$ & $\mathbf{9 6 , 7 0 \%}$ \\
\hline
\end{tabular}

Tabel 03 menunjukkan bahwa sebanyak 96,70\% (151 orang peserta didik) memberikan pendapat positif tentang kartu gerak aktivitas pengembangan PJOK ini. Hal ini menandakan bahwa kartu gerak aktifitas pengembangan PJOK memiliki tampilan gambar dan tulisan yang terlihat jelas, gambarnya menarik, tulisan mudah dipahami, kartu gerak mudah digenggam dan dibawa, aman dan nyaman digunakan serta kartu gerak mudah dimasukkan ke dalam kotak kemasan.

Pembelajaran PJOK mengantarkan peserta didik memiliki pengalaman belajar gerak yang sesuai dengan tingkat pertumbuhan dan perkembangannya. Menurut Wuest and Bucher (1995), gerak merupakan kunci dari pendidikan jasmani dan olahraga. Untuk itu guru pendidikan jasmani diharapkan mampu mewujudkan dan memotivasi peserta didik bergerak sesuai dengan karakteristik tubuhnya. Lebih lanjut Bart Crum menyatakan bahwa:

[...] In primary education the classes are focused on a solid basis of movement 'vocabulary' and movement 'grammar', on development of a personal movement identity of the children. In secondary education the focus shifts to the enhancement of movement cultural competencies.

Pernyataan di atas mengandung makna bahwa, mata pelajaran PJOK di pendidikan dasar difokuskan pada pengembangan perbendaharaan gerak dan ketentuan gerak. Sedangkan pada pendidikan menengah fokus pada peningkatan kompetensi dan keterampilan gerak.
Peran guru PJOK dalam mengelola pembelajaran memperhatikan berbagai hal, salah satunya kegembiraan/ kesenangan (enjoyment). Menurut Jenna R. Lorusso, Stefanie M. Pavlovich dan Chunlei Lu, kesenangan dalam pembelajaran PJOK dapat meningkatkan partisipasi aktif siswa dalam pembelajaran serta membentuk pola hidup aktif (active lifestyles), mempermudah guru dalam mengelola kelas, mengembangkan siswa secara utuh-menyeluruh, serta meningkatkan status dan penerimaan PJOK di sekolah.

Penelitian-penelitian yang relevan adalah: 1) Ary Nur Wahyuningsih (2012) menyimpulkan bahwa media pembelajaran komik bergambar dapat meningkatkan ketuntasan hasil belajar peserta didik, meningkatkan minat peserta didik, dan mendapat respon positif dari peserta didik serta guru, 2) Kristian Tantra Sidarta dan Tri Nova Hasti Yunianta (2019) media Kartu Domano valid, efektif, dan praktis digunakan sebagai sarana latihan belajar mandiri untuk siswa dalam kursus Trigonometri, dan 3) Made Agus Wijaya (2015) menyimpulkan model pembelajaran kooperatif berbasis gerak dasar dengan alat bantu kartu gerak terbukti secara empirik dan praktis diimplementasikan oleh guru dan siswa, serta efektif meningkatkan keterampilan gerak dasar siswa kelas IV SD di Kabupaten Buleleng.

\section{Simpulan dan Rekomendasi}

Berdasarkan pembahasan hasil penelitian diatas, diketahui bahwa: 1) tahap pengembangan media pembelajaran berbasis kartu gerak aktifitas pengembangan PJOK untuk pendidikan dasar dan menengah di Kabupaten Buleleng mengikuti tahapan penelitian pengembangan yang dikemukakan oleh Borg and Gall, 2 2) sosok model media pembelajaran berbasis kartu gerak aktifitas pengembangan PJOK untuk pendidikan dasar dan menengah di Kabupaten Buleleng terdiri atas 3 (tiga) varians berdasarkan tingkat kesulitan kartu gerak yaitu kartu gerak aktifitas pengembangan PJOK pada tingkat kesulitan mudah, sedang dan sulit, serta 3) 95,76\% (68 orang peserta didik) memberikan pendapat positif tentang kartu gerak aktivitas pengembangan PJOK pada saat ujicoba kelompok kecil meningkat menjadi $96,70 \%$ (151 orang peserta didik) pada saat ujicoba kelompok besar. Sehingga simpulan penelitian ini adalah kartu gerak aktivitas pengembangan PJOK dapat diimplementasikan pada satuan pendidikan dasar dan menengah. 


\section{Daftar Pustaka}

Borg, W.R. \& Gall, M.D. Gall. (2005). Educational Research: An Introduction, Eighth Edition. New York: Longman Publisher.

Crum. Bart. (2009). From Crisis to Revival-on Justification of PE as a School Subject and PE Curriculum Development in The Netherlands. Vol. 28, No. 2, pp. 43-49 (diakses 20 November 2018).

Jenna R. Lorusso, Stefanie M. Pavlovich dan Chunlei Lu. (2013). Developing Student Enjoyment in Physical Education. Physical \& Health Education Journal: Summer, 2013; 79,2: ProQuest (diakses 20 November 2018)

Katherine T. Thomas, Amelia M. Lee dan Jerry R. Thomas. (2008). Physical Education for Elementary Teacher, Illinois: Human Kinetics, h. 10.

Kemendikbud, 2013. Implementasi Kurikulum 2013. Jakarta: Kemendikbud.

Maksum, Ali. (2011). Kualitas Guru Pendidikan Jasmani di Sekolah: Antara Harapan dan Kenyataan. Surabaya: Unesa Press.

March L. Krotee dan Charles A. Bucher. (2007). Management of Physical Education and Sport: Thirteenth Edition. USA: McGraw-Hill.

Peraturan Menteri Pendidikan Nasional (Permendiknas) Nomor 22 tahun 2006 Tentang Standar Isi untuk Satuan Pendidikan Dasar dan Menengah.

Peraturan Pemerintah RI Nomor 32 Tahun 2013 tentang Standar Nasional Pendidikan.

Pusat Pengkajian dan Pengembangan IPTEK Olahraga. (1999). "Panduan teknis Tes \& latihan
Smaldino, Sharon E, Deborah L. Lowther, James D. Russel, (2008). Instructional Technology \& Media For Learning Teknologi Pembelajaran dan Media untuk belajar. New Jersey: Pearson Prentice Hall.

Wahyuningsih, Ary Nur. (2012). Pengembangan Media Komik Bergambar Materi Sistem Saraf untuk Pembelajaran yang Menggunakan Strategi PQ4R Journal of Innovative Science Education http://journal.unnes.ac.id/sju/index.php/j ise

Wijaya, Made Agus. (2015). Developing Fundamental Movement Based Cooperative Learning Model In Primary School. Indonesian Journal of Educational Review; p-ISSN 2338-2015; e-ISSN 2335-8407 Vol.2, No.1, March 2015, p 13-24.

Wuest D.A \& Bucher C.A. (1995). Foundation of Physical Education and Sport. St. LouisMissouri: Mosby-Year Book Inc.

Lutan, Rusli. (2002 a). Mengajar Pendidikan Jasmani Pendekatan Pendidikan Gerak di SD. Jakarta: Depdiknas-Ditjora.

(2002 b). Asas-Asas Pendidikan Jasmani Pendekatan gerak di SD. Jakarta: Depdiknas-Ditjora.

Sidarta, K., \& Yunianta, T. (2019). Pengembangan Kartu Domano (Domino Matematika Trigono) Sebagai Media Pembelajaran Pada Matakuliah Trigonometri. Scholaria: Jurnal Pendidikan Dan Kebudayaan, 9(1), 6275.https://doi.org/https://doi.org/10.2424 6/j.js.2019.v9.i1.p62-75

Smaldino, Sharon E, Deborah L. Lowther, James D. Russel, (2008). Instructional Technology \& Media For Learning Teknologi Pembelajaran dan Media 
untuk belajar. New Jersey: Pearson Prentice Hall.

Wahyuningsih, Ary Nur. (2012). Pengembangan Media Komik Bergambar Materi Sistem

Saraf untuk Pembelajaran yang Menggunakan Strategi PQ4R Journal of Innovative Science Education

Wijaya, Made Agus. (2015). Developing Fundamental Movement Based Cooperative Learning Model In Primary School. Indonesian Journal of Educational Review; p-ISSN 2338-2015; e-ISSN 2335-8407 Vol.2, No.1, March 2015, p 13-24.

Wuest D.A \& Bucher C.A. (1995). Foundation of Physical Education and Sport. St. LouisMissouri: Mosby-Year Book Inc. 